International Journal of Linguistics, Literature and Culture
Available online at https://sloap.org/journals/index.php/ijllc/
Vol. 5, No. 5, September 2019, pages: 1 6
$\begin{aligned} & \text { ISSN: 2455-8028 } \\ & \text { https://doi.org/10.21744/ijllc.v5n5.719 }\end{aligned}$

\title{
A Cross-cultural Analysis of Female Protagonist on Selecting Novel of Chitra Banarjee Divakaruni and Bharati Mukherjee
}

CrossMark

G. Sankar ${ }^{a}$

J. Prabhavathi ${ }^{\text {b }}$

S. Sankarakumar ${ }^{\mathrm{c}}$

\section{Article history:}

Received: 09 January 2019

Accepted: 31 July 2019

Published: 28 August 2019

\section{Keywords:}

cross-culture;

cultural values;

feminism;

post colonialism;

subjections;

\begin{abstract}
In the $21^{\text {st }}$ century, women's writing in English has been considered as a powerful medium of modernism and feminist proclamation in the contemporary society of patriarchy life. The last two decades have witnessed extraordinary success in feminist writings of Indian English literature even Today is the generation of those women writers who are rich and have been educated in the West. Hence, this paper examines to analysis the crosscultural values and divulgences of female protagonist's of the great diasporic writers Chitra Banarjee Divakaruni and Bharati Mukherjee select novels. It also discussed the problems of women and in their suppressions in our postmodern society how they lost their identity and how do they feel their separation of culture from native land to an alien land.
\end{abstract}

2455-8028 ${ }^{\circledR}$ Copyright 2019. The Author. This is an open-access article under the CC BY-SA license (https://creativecommons.org/licenses/by-sa/4.0/) All rights reserved.

\section{Author correspondence:}

G. Sankar,

Assistant Professor of English PSG College of Technology Coimbatore, India

Email address: sankarliterature@gmail.com

\section{Introduction}

Chitra Banarjee Divakaruni and Bharati Mukherjee is a well-known novelist both are also very famous writers in Indian Writing in English. Many of their writings have been dealt with by some of Indians and the USA, feature Indian-born women torn between new and old-world values. Their stories give a laser-like insight into the feminine nature. their skilled use of story, plot and lyrical description gives the readers a many-layered looks at their characters and their respective worlds which are filled with fear, hope, and discovery. Most of their works are autobiographical and are based on the lives of Indian immigrants. They have dealt with their lives and its many nuances in detail. They said to writes the unite people by breaking down old stereotypes (Nayar, 2008; Nelson, 2017; Sankar \& Soundararajan, 2018).

a PSG College of Technology Coimbatore, India

${ }^{b}$ PSG College of Technology Coimbatore, India

${ }^{c}$ PSG College of Technology Coimbatore, India 


\section{Materials and Methods}

In 1997, Divakaruni first novel The Mistress of Spices. It is a dazzling tale of misbegotten dreams and desires, hopes and expectations, woven with poetry and storyteller magic. Divakaruni says about her first novel the following: "I wrote in a spirit of play, Collapsing the division between the realistic world of twentieth-century America and the timeless one of the myth and magic in my attempt to create a modern fable" (1990; 02).The main character of the book Tilo owns a spice shop in an Indian community in Oakland, California. She becomes involved in the lives of the customers and helps them by guarding them against abusive husbands, racism, generational conflicts, and drug abuse (Mishra, 2007; Mohan \& Kumar, 2018; Naik \& Narayan, 2001). The book was short-listed for the Orange Prize from England and was named one of the best books of 1997 by the Los Angels Times. But, Mukherjee's female protagonists like Hannah Easton in The Holder of the World, Devi in Leave It to Me, Three daughters of Bhattacharya family, Padma, Parvati, and Tara in Desirable Daughters and Tara Lata in The Tree Bride. They are stated facts about Mukherjee's ideology on betrayal of women and searching for the identity. Mukherjee has confirmed frankly that she is nostalgic about India but she has no remorse and state publicly that she is an American citizen. These novels mainly focus on the diasporic situations and dislocations of Mukherjee own lives too, however, she has been describing the element of immigrant consciousness and nostalgia in the wider sense and dimensions of nostalgia are far extended beyond the sentimental longing, to encompass all the meaning - exile, displacement, dislocation, relocation, expatriation and assimilation (Emmanuel Catherine, 2009; Junaidi, 2018; Mishra, 2016).

Furthermore, Mukherjee has paid special attention to the condition of the Indian woman immigrant in North America. Pradeep Trikha has mentioned that in her 1990 Iowa Review Interview: "Bharati Mukherjee emphasizes that many of her stories are about psychological transformation; especially among women emigrate from Asia" (178). Her heroines endeavor for self-realization as Hannah Easton in The Holder of the World, Devi in Leave it to $m e$ and the three daughters of Bhattacharyya family namely Padma, Parvati and Tara in Desirable Daughters and Tara in Tree Bride. Mukherjee does not impose readymade solutions to the problems facing immigrant. She prefers showing them gradual acquiring power in order to control their fate. They offer role models for several immigrant women. As Fakrul Alam observes:

Once literature begins to serve as a forum illuminating female experience, it can assist in humanizing and equilibrating the cultural value system, which has served predominantly male interests. A literary work is capable of providing role models, instill a positive sense of feminine identity by portraying women who are selfactualizing, whose identities are not dependent on men. (128)

Mukherjee's The Holder of the World is a feminist novel. It is a tale of dislocation and transformation of two cultures between India and America. The present novel is about the story of women protagonist Hannah Easton, She is an abandoned child came to India in the seventeenth century and imbedded herself in its culture. As Arshia Sattar states in the review of this novel:

(The novel) has a wide canvas that sweeps across continents and centuries, cultures and religions, immigration, exile, alienation, and foreign lands have always been the color of Mukherjee's palate and with The Holder of the World she uses the familiar tones and shades to create a universe of infinite possibility and eternal time. (24)

However, Divakaruni once explained the reason for writing: “There is a certain spirituality, not necessarily religious - the essence of spirituality - that is at the heart of the Indian psyche, that finds the divine in everything. It was important for me to start writing about my own reality and that of my community" (Double Day, 156). Anju is the daughter of an upper-caste Calcutta family of distinction. Sudha is the daughter of the black sheep of that same family (Barry, 2017; Beauvoir, 1972; Divakaruni, 2010). Sudha is startlingly beautiful; Anju is not. Despite these differences, since the day the two girls were born the same day their fathers died. Mysteriously and violently Sudha and Anju have been sisters of the Heart. Bonded in ways even their mothers cannot comprehend, the two girls grow into womanhood as if their fates, as well as their hearts, are merged. Due to a change in family fortune, the girls are Urged into arranged marriages, their lives take opposite turns. One travels to America and on remains in India. When tragedy strikes both of them, however, they discover that, despite distance and marriage, they must turn to each other once again.

"Like the old tales of India that are filled with emotional filigree and flowery prose, Divakaruni's (The Mistress of Spices) latest work is masterful allegory of unfulfilled desire and sacrificial love. It is also an intricate modern 
drama in which generations and castes struggle over old and new mores. Anju and Sudha are cousins, born in the same household in Calcutta on the Same Day? Which is also the day on which their mothers learn that both their husbands have been killed in a reckless quest for a cave full of rubies?

Sudha grows up believing her father was a no-good schemer who brought ruin on his cousin, Anju's upper-class father. AS they mature, Anju dreams of college, Sudha of children, but arranged marriages divide and thwart them. Anju adjusts to life in California with a man who lusts after Sudha; Sudha grapples with a mother-in -low ho turns to the goddess shasti to fill Sudha's barren womb rather than to a doctor for her sterile son. Ultimately, the tie between Anju and Sudha supersedes all other love, as each sustains painful loss to save the other, When Sudha learns the truth about her father and no longer needs to right his wrongs, she sees that all along her affection for Anju has not been dictated by necessity. An inspired and imaginative raconteur, Divakaruni's is sure to engender comparisons with Arundhati Roy (The God of small things), but Divakaruni's novel stands in its own right as a compelling read mesmerizing narrative." "like Rebecca Wells's Secrets of the Ya-Ya Sisterhood, Divakaruni,s debut novel, The Mistress of Spices was a word - of - mouth hit ; its blend of magical realism and culinary sensuality also appealed to fans of Laura Esquivel's Like Water for Chocolate (Aini, 2017; Alam, 1996; Ashcroft et al., 1998).

Divakaruni was inspired by many writers. Dabydeeen and Asoka Weerasinghe are two of them. In the evolving history of South Asian Canadian literature, Dabydeen occupies a special place. He is not only a prolific writer-he has published over a dozen volumes of fiction and poetry-but also a writer who has conscientiously worked to gain recognition for minority writers in Canada. Dabydeen's Stoning the Wind is a collection of fifty-eight poems. He is at most poetic when he uses images from his native landscape. Many of his poems are dedicated to individuals, and several of them directly pay tribute to a friend by remembering small, specific incidents.

Tears for My Roots are a slender volume of twenty-five poems by Ashoka Weerasinghe. He published several such volumes since 1968 when he immigrated to Canada from his native Sri Lanka via England. Its main interest lies in the use of newspaper clippings and photographs, ink-sketches of temple sculptures; and a refrain of silhouetted figures of elephant and dancers at border of each page add a dimension to the reading experience.

"Chitra Banarjee Divakaruni is a new name, which is likely to become more familiar. There is no doubt about the presence of poetic talent in Black Candle. The volume looks, feels and reads the way poetry should. The font used is aesthetic. The cover picture in purple, blue, and orange showing a cobra with raised hood is evocative of the power of fear of female sexuality. The book is dedicated to her mother and "for my sisters of the South Asian Diaspora," the subtitle is "Poems about Women from India, Pakistan, and Bangladesh" (98).

But in Mukherjee's The Holder of the World is a unique fusion of fiction and History. Mukherjee uses the technique of virtual reality as a trope for dislocating and transforming literary, cultural, and historical topographies of Mughal in India and colonial $17^{\text {th }}$ and $18^{\text {th }}$ century United States. Mukherjee exposes the snobbery, hypocrisy and corrupt world of East India Company's rule in India. Hannah, a puritan American woman, visits India along with her husband and discovers true happiness in the company of a Hindu Raja-Jadav Singh and who returns home and changed and transformed a human being. When Hannah came to India from America she lost her identity and consciousness of western culture. Malikarjun Patil observes: "The novel is a candid depiction of 1970's life of an American woman whose lifestyle of functioning is totally untraditional, and whose mind, is tom due to her cloudy headedness" (66). It depicts an American Woman's exile to India and spoiling of her own self-conscience.

In Bharati Mukherjee's earlier novels, the protagonists' journey commences from the East and it ends in the West but in The Holder of the World the protagonist's journey begins from the West and it ends in the East. The novel revolves sound on the lives of two white women, Hannah Easton who was from the 17th century American Puritan world and Beigh Master who is the narrator of the novel respectively, whereas her first three novels are Indian protagonist who travels from the East to the West. Beigh Master is assets hunter and at present, she enthusiastically reconstructs the life of Hannah Easton. She does the work to find lost possessions of the people. Hannah holds the opinion:

People and their property often get separated or people want to keep their assets hidden. Nothing is ever lost, but continents and centuries sometimes get in the way. Uniting people and possessions; it's like matching orphaned socks, through times. (5)

The Holder of the World Mukherjee expresses the experiences of relocation and dislocation of Hannah Easton, is a Puritan American. Her quest is for self-realization and independence. She wants to free herself from orthodox Puritan world. She follows the footsteps of her mother. Hannah is daughter of Edward Easton and Rebecca Easton. Edward

Sankar, G., Prabhavathi, J., \& Sankarakumar, S. (2019). A cross-cultural analysis of female protagonist on selecting novel of chitra banarjee divakaruni and bharati mukherjee. International Journal of Linguistics, Literature and Culture, 5(5), 1-6. https://doi.org/10.21744/ijllc.v5n5.719 
Easton has died of bee sting when Hannah is one year old. Her mother becomes widow at the age of twenty-two years. Rebecca suffers from loneliness and she falls in love with Nipmuc man. Rebecca runs away with Nipmuc man leaving behind Hannah.

\section{Results and Discussions}

Thus, The Protagonists Hannah and Jasmine both are raised in traditional society they face many problems which transforming themselves to modern society and culture. Hannah wants to get freedom from the strict Puritan society but she cannot revolt against society and she is not clear about her aim in life. On the other hand Jasmine is also born in gender-biased society where daughter is curse but she revolts against conventional norms of the society from the beginning. She is very clear about her goal. Jasmine and Hannah both never think to return their motherland. Jasmine assimilates in American culture. Hannah, in the beginning, socializes only with the Englishwomen because the local people cannot enter into the White Town. The Chief Factor Cephus Prynne allotted the Legges Late Chief Factor Henry Hadges house (Abrams \& Harpham, 2011; Agarwal, 2007).

Bhagmati worked for Henry Hedges and she stays in the house even after the death of Henry Hedges. Hannah hires Bhagmati as her maid. Hannah socializes with Martha Ruxton and Sarah Higginbotham. Martha Ruxton and Sarah Higginbotham always remain nostalgic about her life in England and they want to return England after completion of her husband's work. Hannah wants to explore varieties of the Coromandel Coast. Bhagmati tells her stories about the Mahabharata and the Ramayana epics. She is Hannah's only companion when Gabriel is on the voyage. Hannah and Bhagmati share common language. Hannah asks her about the Lord Hanuman. Bhagmati tells her about the story of the legendary Sita and how she sacrifices her life for the love of her husband Rama. Hannah compares her mother Rebecca's life with the legendary Sita. She thinks that her mother prefers to live with Ravana instead of Rama.

However, In the novel The Mistress of My Heart, Divakaruni represents all the major problems of women who belong to the Diaspora. She describes realistically how women are ill-treated by their abusive husbands, how they are bullied by their fathers-in-law and mother-in-law, and how they lose their female identity and individuality. The novel also offers solutions to the problems of women who are enslaved by mythological beliefs and abusive restrictions and conventions of the Indian family system. Moreover, the novel The Mistress of My Heart tries to evolve a female identity in the novel, which can emancipate women from their traditional bonding and abusive relationships.

\section{Conclusion}

Both the writer's novels represent women's lives and their various problems. They do this by contrasting western culture and Indian culture. They tend to praise excessively the American traditions and ways of life and the freedom they are thought to afford to women and to underestimate the Indian traditional values and ways of life. The reason for the partial treatment of the Indian traditional values might be the fact that these novels were written mainly for western readers.

\section{Conflict of interest statement}

The authors declared that they have no competing interest.

\section{Statement of authorship}

The authors have a responsibility for the conception and design of the study. The authors have approved the final article.

\section{Acknowledgments}

The authors would like to thank the editor of IJLLC for their valuable time, support, and advice on completing the current study. 


\section{References}

Abrams, M. H., \& Harpham, G. (2011). A glossary of literary terms. Cengage Learning.

Agarwal, B. (2007). Cross-Cultural Dilemma in Bharati Mukherjee's Desirable Daughters. New Perspectives on Indian English Writings, 271.

Aini, Z. (2017). The actualization of cultural elements in novel Guru Onyeh by Salman Faris. International Journal of Social Sciences and Humanities, 1(3), 17-27. https://doi.org/10.29332/ijssh.v1n3.49

Alam, F. (1996). Bharati Mukherjee: Criticism and Interpretation. New York: Twayne's United States Author's Series, 285.

Ashcroft, B., Griffiths, G., \& Tiffin, H. (1998). Key concepts in post-colonial studies. Psychology Press.

Barry, P. (2017). Beginning theory: An introduction to literary and cultural theory. Oxford University Press.

Beauvoir, S. D. (1972). The Second Sex, trans. HM Parshley. Jonathan Cape Ltd, London.

Divakaruni, C. (2010). The Mistress Of Spices: Shortlisted for the Women's Prize. Random House.

Emmanuel Catherine, L. A. (2009). Cultural dichotomy as Leitmotif a study of the fictional writings of Bharati Mukherjee.

Junaidi, L. M. (2018). Stereotypes as the Ideology of Feminism in Novels Authorized by Indonesian Female Authors. International Journal of Linguistics, Literature and Culture, 4(1), 1-15.

Mishra, A. K. (2016). Diaspora, development and the Indian state. The Round Table, 105(6), 701-721.

Mishra, V. (2007). The literature of the Indian diaspora: theorizing the diasporic imaginary. Routledge. https://doi.org/10.4324/9780203932728

Mohan, N., \& Kumar, S. S. (2018). From the individual to the historical: a commentary on amitav ghosh as a writer of historical fiction with reference to the glass palace. International Journal of Social Sciences and Humanities, 2(3), 79-85. https://doi.org/10.29332/ijssh.v2n3.203

Naik, M. K., \& Narayan, S. A. (2001). Indian English Literature, 1980-2000: A Critical Survey. New Delhi: Pencraft International.

Nayar, P. K. (2008). Postcolonial Literature: an introduction. Pearson Education India.

Nelson, E. S. (2017). Bharati Mukherjee: Critical Perspectives. Routledge.

Sankar, G., \& Soundararajan, R. (2018). Transnational identity of assimilation and assertion in Bharati Mukherjee miss new India. International Research Journal of Management, IT and Social Sciences, 5(6), 9-16. https://doi.org/10.21744/irjmis.v5n6.328

Sankar, G., Prabhavathi, J., \& Sankarakumar, S. (2019). A cross-cultural analysis of female protagonist on selecting novel of chitra banarjee divakaruni and bharati mukherjee. International Journal of Linguistics, Literature and Culture, 5(5), 1-6.

https://doi.org/10.21744/ijllc.v5n5.719 


\section{Biography of Authors}

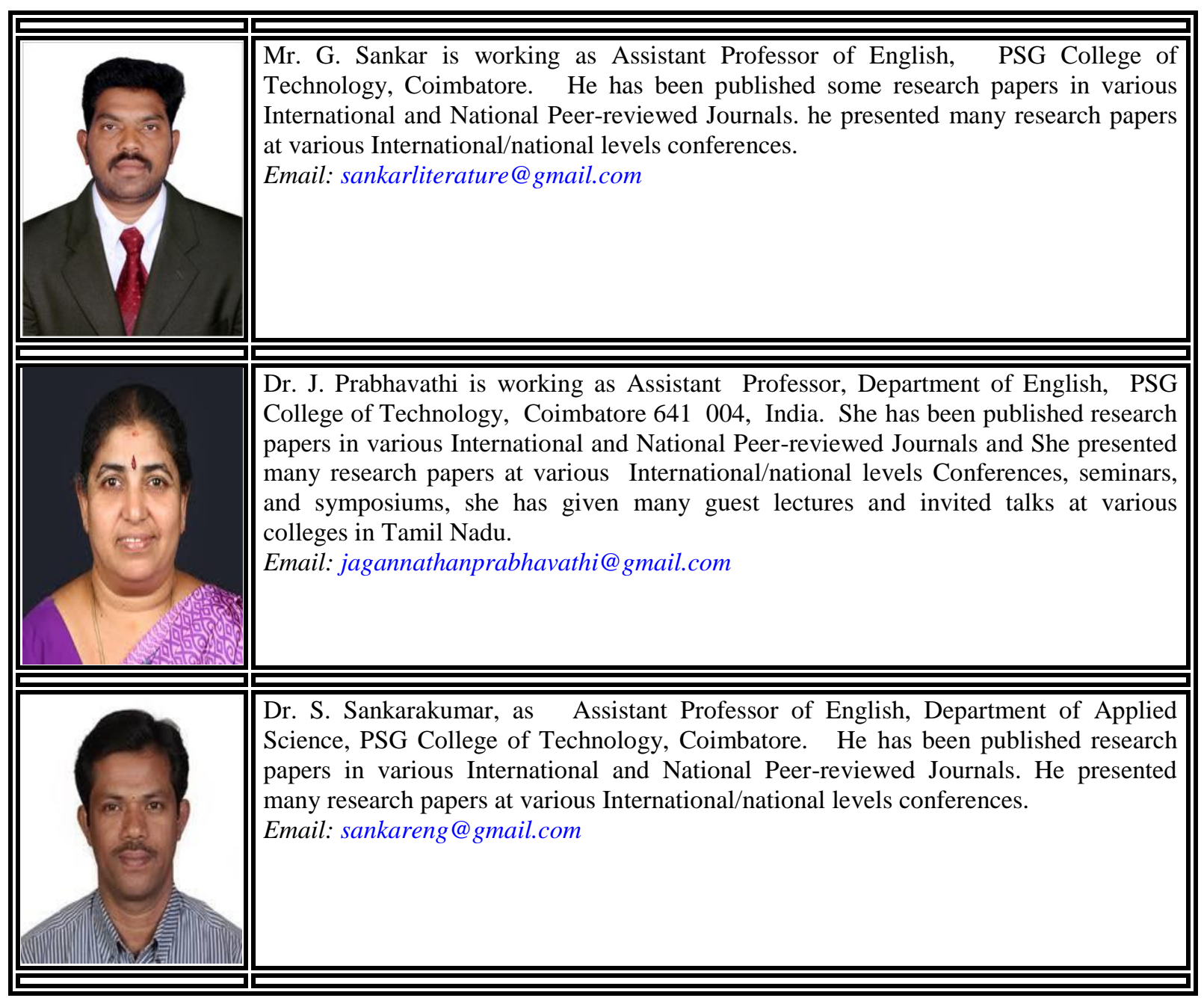

